The thoron-tartaric acid systems for the spectrophotometric

\title{
determination of thorium
}

By F. S. Grimaldi and Mary H. Fletcher

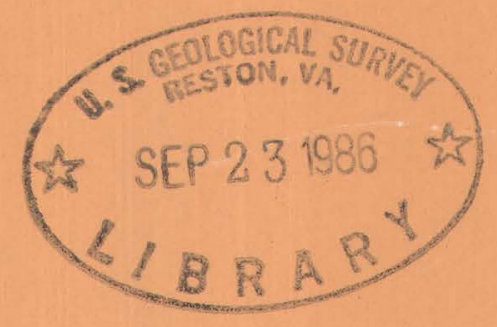

Trace Elements Investigations Report 571

Anal. Chemiotay, 1.28, na.5, p.812-816, 19.6.

UNITED STATES DEPARTMENT OF THE INTERIOR GEOLOGICAL SURVEY 


\section{Chemistry}

This document consists of 25 pages. Series A.

UNITED STATES DEPARTMENT OF THE INTERIOR

GEOLOGICAL SURVEY

THE THORON-TARTARIC ACID SYSTEMS FOR THE

SPECTROPHOTOMETRIC DETERMINATION OF THORIUM*

By

F. S. Grimaldi and Mary H. Fletcher

September 1955

Trace Elements Investigations Report 571

This preliminary report is distributed without editorial and technical review for conformity with official standards and nomenclature. It is not for public

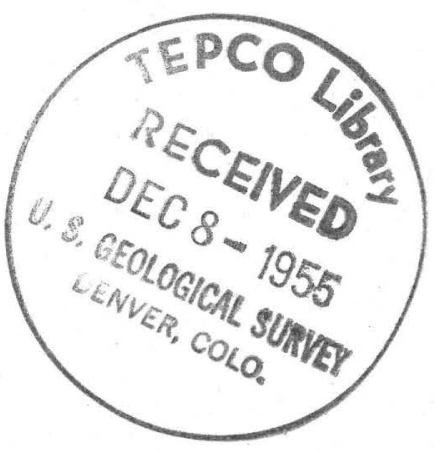
inspection or quotation.

*This report concerns work done on behalf of the Division of Raw Materials of the U. S. Atomic Energy Commission. 
USGS - TEI $=571$

\section{CHEMISTRY}

Distribution (Series A)

Argonne National Iaboratory ............................. I

Atomic Energy Commistsion, Washington .................... 2

Battelle Memorial Institute, Columbus .................... 1

Carbide and Carbon Chemicals Company, $Y=12$ Area ............. I

Division of Raw Materials, Albuquerque .................... I

Division of Raw Materials, Butte .......................... 1

Division of Raw Materials, Casper ........................ 1

Division of Raw Materials, Denver ........................ I

Division of Raw Materials, Hot Springs ................... I

Division of Raw Materials, Ishpeming .................... I

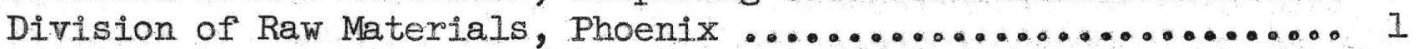

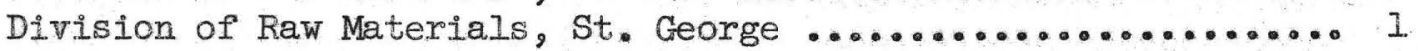

Division of Raw Materials, Salt Lake City .................. I

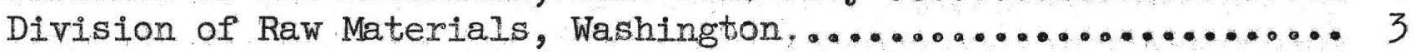

Dow Chemical Company, Pittsburg ........................ 1

Exploration Division, Grand Junction Operations Office ........ I

Grand Junction Operations Office ........................ I

National Iead Company, Winchester ....................... 1

Technical Information Service, Oak Ridge .................. 6

Tennessee Valley Authority, Wilson Dam ..................... 1

U. S. Geological Survey:

Fuels Branch, Washington ............................. 1

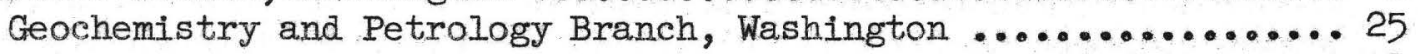

Geophysics Branch, Washington .......................... 1

Mineral Deposits Branch, Washington ..................... 1

E. H. Bailey, Menlo Park ............................... I

A. Lo Brokaw, Grand Junction ............................. 1

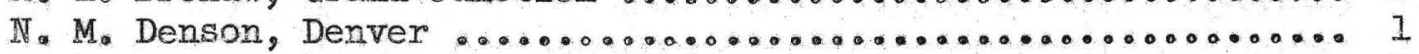

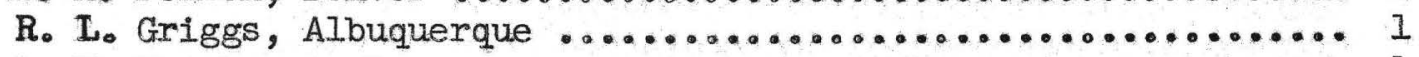

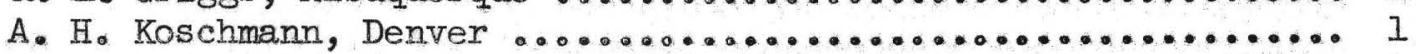

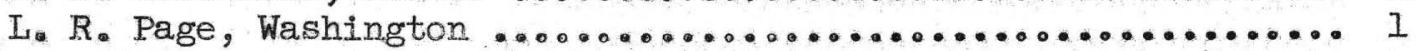

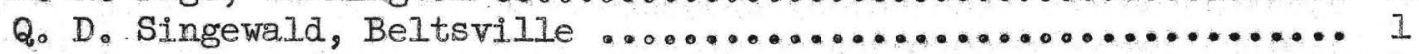

A. E. Weissenborn, Spokane $\ldots \ldots \ldots \ldots \ldots \ldots \ldots \ldots \ldots \ldots \ldots \ldots \ldots \ldots \ldots \ldots$

TEPCO, Denver ....................................... 2

TEPCO, RPS, Washington, (including master) $\ldots \ldots \ldots \ldots \ldots \ldots \ldots \ldots$ 


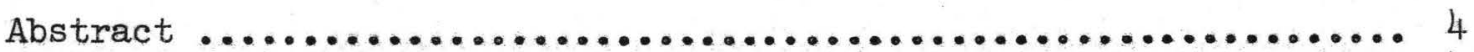

Introduction ............................................. 4

Experimental data ......................................... 5

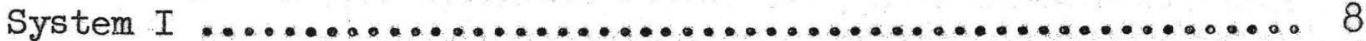

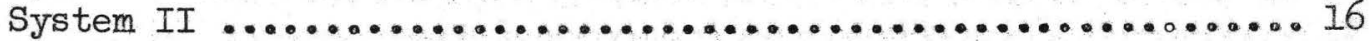

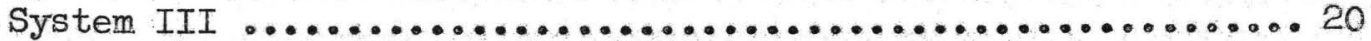

Spectrophotometric determination of thorium in monazite

concentrates ..............................................20

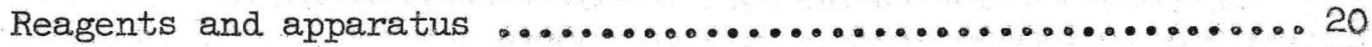

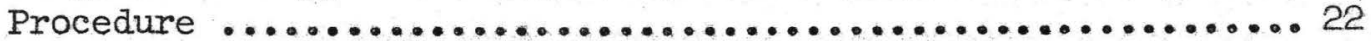

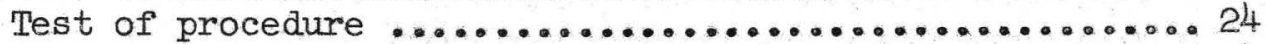

Acknowledgments ............................................24

Literature cited .....................................25

\section{ILLUSTRATIONS}

Figure 1. Zirconium interference in absence of tartaric acid ....6 6

2. Effect of tartaric acid, system I ................. 9

3. Spectra of zirconium and blank solutions ............... Il

4. Effect of zirconium at various concentrations of thorium and tartaric acid ........................13

5. Effect of tartaric acid, system II ................ I7

6. Effect of thoron concentration ................... 18

7. Effect of acidity, system II .................... 19

8. Effect of meso-tartaric acid, system III .............2I

\section{TABLES}

Table 1. Milligrams of various elements (as oxides) equivalent to 1 microgram of thorium dioxide .................... I4

2. Test of procedure on monazite sand ................. 24 
THE THORON-TARTARIC ACID SYSTEMS FOR THE

SPECTROPHOTOMETRIC DETERMINATION OF THORIUM

By F. S. Grimaldi and Mary H. Fletcher

ABSTRACT

Thoron is popularly used for the spectrophotometric determination of thorium. An undesirable feature of its use is the high sensitivity of the reagent toward zirconium. This study describes the use of tartaric acid as a masking reagent for zirconium. Three tartaric acid-thoron systems, developed for the determination of thorium, differ with respect to the concentrations of thoron and tartaric acid. Meso-tartaric acid, used in one of the systems, is found to be most effective in masking zirconium. The behavior of various rarer elements, usually found associated with thorium ores, is determined in two of the systems, and a dilution method is described for the direct determination of thorium in monazite concentrates.

\section{INTRODUCTION}

At present, thoron [the disodium salt of $2-(2-$ hydroxy $-3,6$-disulfo-1naphthylazo)-benzene arsonic acid] is probably the most popular reagent for the spectrophotometric determination of thorium. Originally introduced by Kuznetsov (5) for the detection of thorium, the reaction was developed into a quantitative spectrophotometric procedure by Thomason and others (7). Several important studies and applications of this reaction have been made by Ingles (4), Banks and coworkers $(1,2,3)$, and Taylor and Dillon (6). The report by Byrd and Banks (3) is comprehensive. 
An undesirable feature limiting the use of the thoron spectrophotometric method for thorium is that the reagent is highly sensitive to zirconium. This is shown in figure 1 . where the net absorbance due to zirconium alone and in the presence of $150 \gamma \mathrm{ThO}_{2}$ is plotted. It should be noted that zirconium gives increased absorbance in the presence of thorium. It can be shown that $1 \gamma$ of $\mathrm{ThO}_{2}$ in $25 \mathrm{mI}$ of solution gives a net absorbance of 0.012 for a $5-\mathrm{cm}$ light path. Thus $0.6 \gamma$ of $\mathrm{ZrO}_{2}$ is equivalent to $1 \gamma$ of $\mathrm{ThO}_{2}$ when $150 \gamma$ of thorium dioxide is present. Several organic hydroxy acids were studied as possible masking reagents for zirconium; this report deals with the use of tartaric acid.

The thoron-thorium-tartaric aci.d system is very complex. At least five equilibria are involved: .. thorium-thoron, thorium-tartrate, zirconium-thoron, zirconium-tartrate, and thoron-tartrate. The last equilibrium must be considered because thoron and tartaric acid also react. An additional variation is introduced when meso-tartaric acid is substituted for the common do tartaric acid.

\section{EXPERIMENTAL DATA}

In systems free from tartaric acid, the acidity of the medium and the concentration of thoron are important factors effecting the thoron thorium reaction. At $\mathrm{pH}$ values above 3 competition between hydroxyl ion and thoron for thorium leads to progressively decreasing apparent absorptivity for the complex. In the range of $\mathrm{pH}$ values $0.5-1.5$ the $\mathrm{pH}$ dependency of the complex is rather small justifying the selection of this range in published analytical procedures for the determination of thorium. However, as the pH is raised from 0.5 to 1.5 more ions interfere and the amounts tolerated become prom gressively sma.ler. 


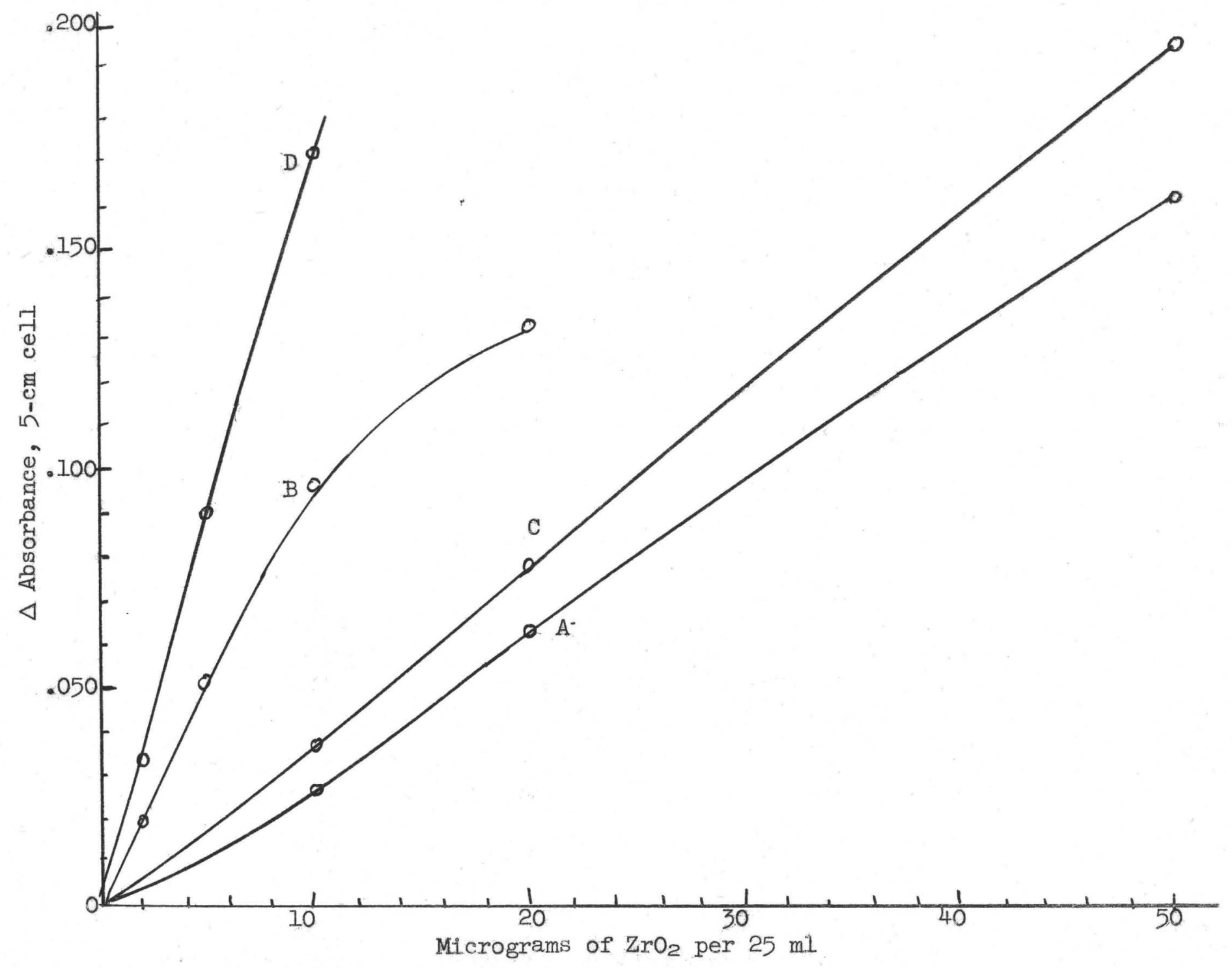

Figure 1.--Zirconium interference in absence of tartaric acid.

$\mathrm{A}, \mathrm{ZrO}_{2}$ vs reagent blank, $2 \mathrm{mg}$ of thoron

$\mathrm{B}$, 150 y $\mathrm{ThO}_{2}$ plus varying $\mathrm{ZrO}_{2}$ VS 150 y $\mathrm{ThO}_{2}$, $2 \mathrm{mg}$ thoron

$\mathrm{C}, \mathrm{ZrO}_{2}$ vs reagent blank, $4 \mathrm{mg}$ thoron

$\mathrm{D}_{2} 150 \gamma \mathrm{ThO}_{2}$ plus varying $\mathrm{ZrO}_{2}$ vs $150 \gamma \mathrm{ThO}_{2}, 4 \mathrm{mg}$ thoron 
The effects of thoron concentration relate to whether sufficient thoron is present to yield full thorium complex (more than a stoichiometric amount of thoron for a 2 thoron: I thorium complex is found to be required). Elements that form strong complexes with thoron may upset the thorium-thoron equilibrium by consuming reagent and causing less of the thorium to be combined. When equilibrium is upset positive or negative errors may arise depending on such factors as the mignitudes of the absorbances of the complexes of the interfering ions, of the thorium complex, and that of unreacted thoron at the wavelength used.

Elements that form weak complexes with thoron are not likely to upset the thorium-thoron equilibrium appreciably. The magnitude of the interference of such elements would depend on the free thoron present which determines the extent of reaction. Such elements would be expected to give greater intereference as the concentration of uncombined thoron is increased.

In our studies on the tartarie acid-thoron systems a high acidity (pH 0.65 ) was chosen to minimize the effect of interfering elements. Three systems were studied. In system I, $2 \mathrm{mg}$ of thoron per $25 \mathrm{ml}$ of final solu. tion was used. This amount is just sufficient to complex 150 y $\mathrm{MHO}_{2}$ at $10 \mathrm{w}$ tartaric acid concentrations. By limiting the thoron concentration it was felt that interference from elements, such as rare earths, that react weakly with thoron would be decreased. In system II, the concentration of thoron was twice that in system I. System. II would be expected to have less anion. interference. In system III, the thoron concentration was the same as in system I but meso-tartaric was substituted for the common d-tartaric acid used in the other two systems.

All experiments were made from a total volume of $25 \mathrm{ml}$. The order of adition of the reagents was always the same: acid first, zirconium in $(1+1)$ 
HCI. solution second, thorium third, hydroxylamine hydrochloride (1. mi of a 10 percent solution) fourth, 30 percent tartaric acid solution fifth, and. thoron last. Two milliliters of 0.1 percent thoron was used in systems I and. III and $4 \mathrm{ml}$ in system II. The total amount of ECI in a.1I solutions amounted to I $\mathrm{ml}$ of ( $1+1$ ) HCI (including that supplied by $\mathrm{Zr}$ solutions). The hydroxylamine hydrochloride is included because it is used in the final procedure to decrease the interference of ferric iron. Absorbances were measured with a Beckman spectrophotometer using 5-cm cells at 545 min, the peak absorption of the thorium-thoron complex.

\section{System I}

The effect of tartaric acid in system $I$ is shown in figure 2. Absorbanees were obtained differentially but are plotted with respect to water as reference. Thoron is seen to react with tartaric acid, progressively increasing absorbances being obtained with increase in tartaric acid (curve D). The thorontartaric acid complex was found to have peak absorption at $533 \mathrm{m \mu}$. The nature of this interaction is not known. The curves for $10 \gamma$ Tho $0_{2}$ (curve C) and $150 \gamma \mathrm{ThO}_{2}$ (curve A) show that as the tartaric acid is increased more of the thorium enters into a tartrate complex. The $10 \gamma$ ThO $\mathrm{O}_{2}$ curve (curve $C$ ) intersects the thoron curve (curve D) at about $5 \mathrm{ml}$ of tartaric acid and then follows the thoron curve. This is apparently due to full release of thorium from its complex with thoron and the complete formation of the thorium tartrate complex. However ten milliliters of tartaric acid is not sufficlent to complex completely 150 y $\mathrm{ThO}_{2}$ (curve A). The situation in regard to solutions containing zirconium is peculiar (curves B, E, and F)。 Small amounts of tartaric acid exert a strong complexing action on zirconium as indicated by a sharp drop in the absorbance curve at small concentratious 


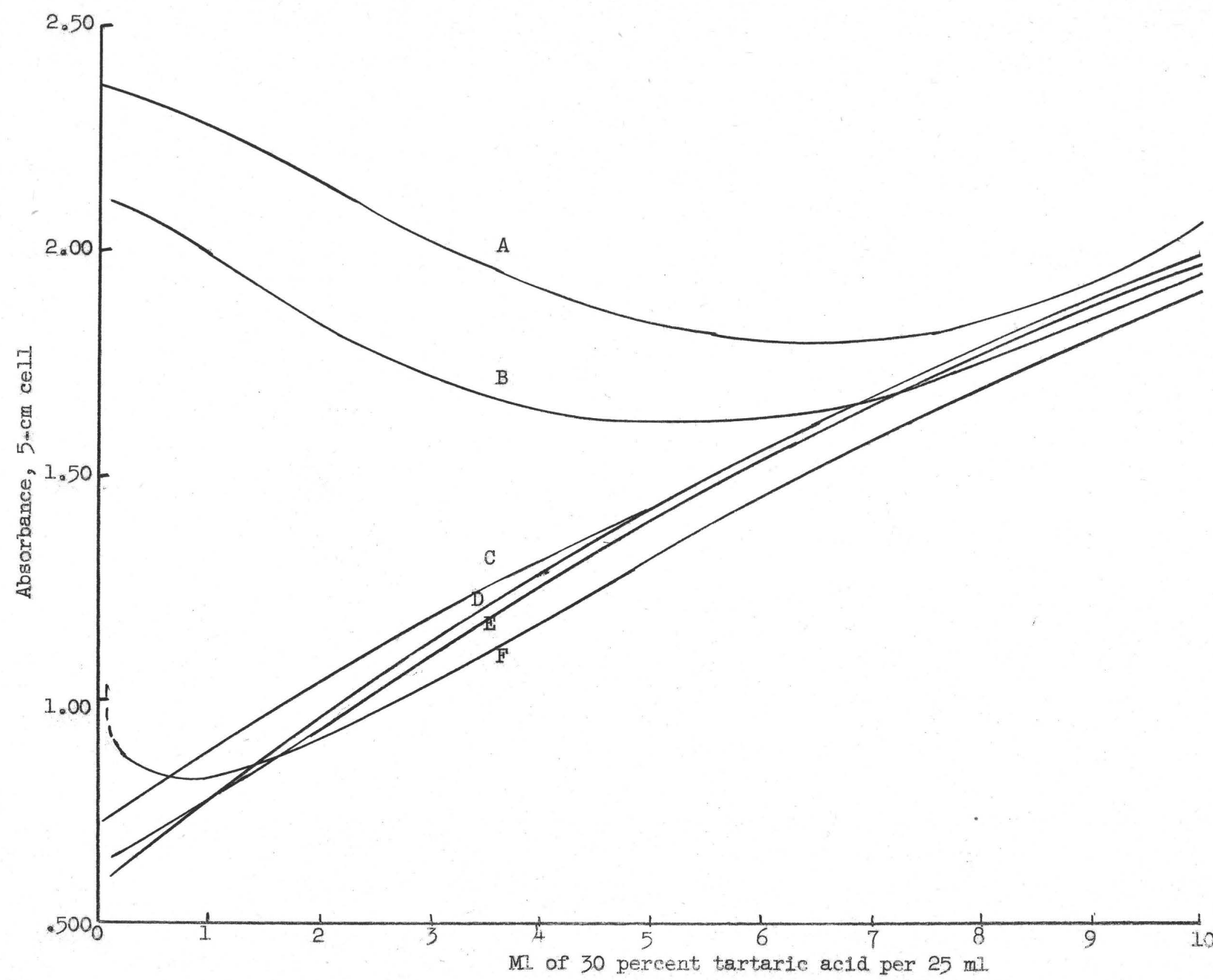

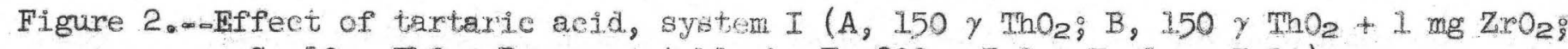
$\mathrm{C}$, Io $\gamma \mathrm{ThO}_{2}$; $\mathrm{D}$, reagent blank: E, 200 y $\mathrm{ZrO}_{2}$; $\mathrm{F}$, I $\mathrm{mg} \mathrm{ZrO}_{2}$ ). 
of tartaric acid.

If full zirconium-tartrate complex were obtained, one would expect that the zirconium curves $\mathrm{E}$ and $\mathrm{F}$ (200 $\gamma$ and $1 \mathrm{mg} \mathrm{ZrO}_{2}$ ) would intersect the thoron curve (D) then coincide with it as the tartaric acid is increased, as was the case for $10 \gamma \mathrm{ThO}_{2}$ in curve $\mathrm{C}$. Actually for these amounts of tartrate, the zirconium solutions absorb less than the thoron and this decrease camat be accounted for simply by the amount of tartaric acid combined with the zirconium. Solutions containing both thorium and zirconium (curve B) show less absorbance than solutions containing only thorium (curve A).

Several theories were postulated and experimental data were obtained to find some basis for explaining the various phenomena. On the basis of the somewhat limited data, no theory gave a satisfying picture. It should be mentioned that polynuclear complexes, molecular chains, geometric and tautomeric equilibria of thoron, meso and other forms of tartaric acid, and intermediate complexes, such as Zr-thoron-tartrate, were considered. At constant tartaric acid concentrations (greater than $5 \mathrm{ml}$ of tartaric acid per $25 \mathrm{ml}$ of solution) the magnitudes of the decrease in absorbance due to zirconium were found to be proportional both to the concentrations of zirconium and of thoron. In figure 3, the solid curve shows the spectra of a reagent blank and the dashed curve the spectra for a solution containing $1 \mathrm{mg} \mathrm{ZrO}_{2}$. Both solutions contained $6 \mathrm{ml}$ of tartaric acid and $2 \mathrm{mg}$ of thoron, and each is compared against a reagent blank free from tartaric acid. There seems to be no evidence of a new absorbing species, but it is doubtful if the effects of small amounts would. be evident. It seems that a small amount of dye-tartrate complex is lost.

It is clear from the nature of the curves plotted in figure 2 that the thorium-thoron reaction would be highly sensitive only for media containing small amounts of tartaric acid. Accordingly, the region up to $2 \mathrm{ml}$ of 
11

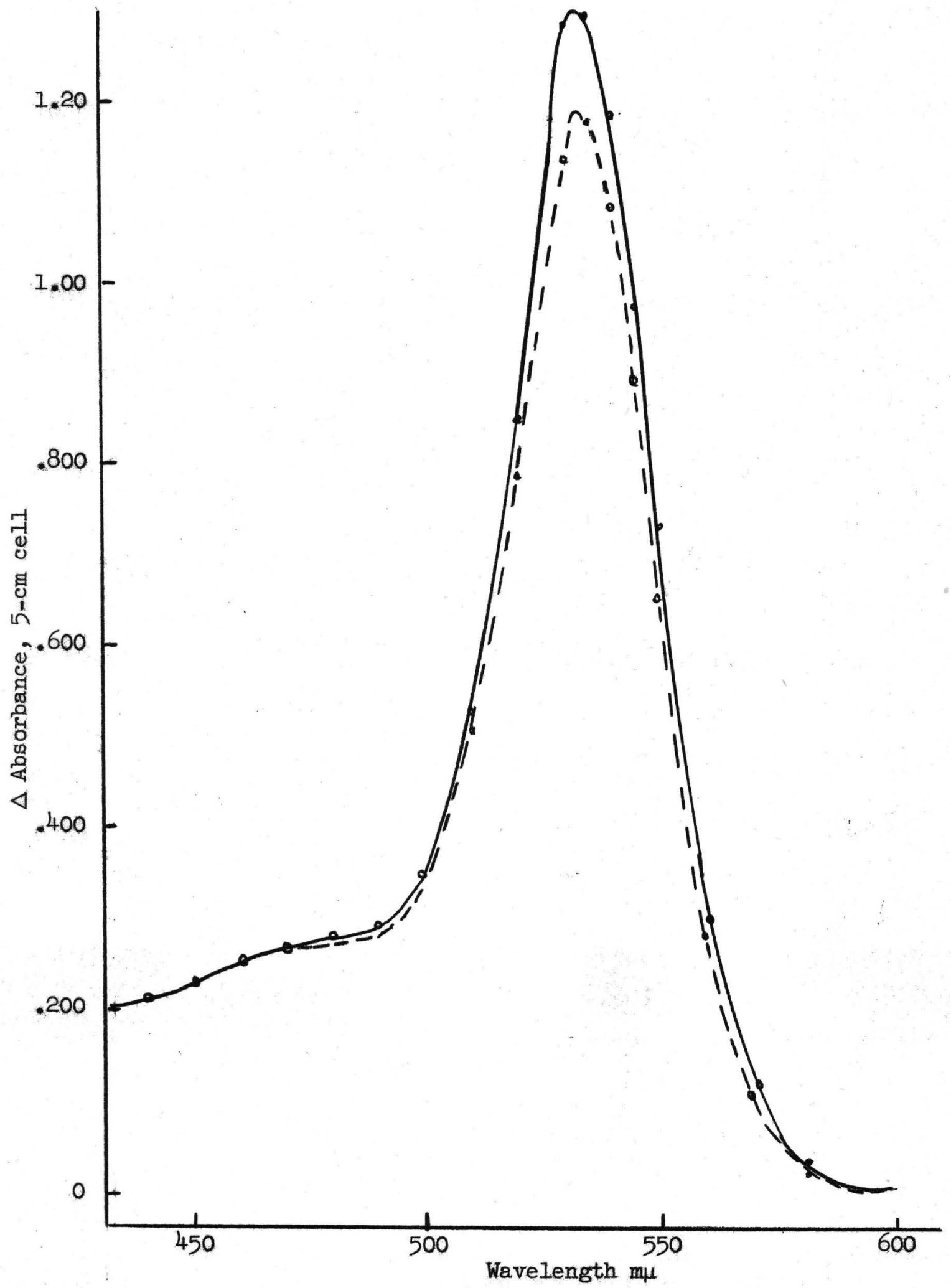

Figure 3.--Spectra of zirconium and blank solutions $6 \mathrm{ml} 30$ percent tartaric acid and $2 \mathrm{mg}$ thoron. (Solid line = reagent blank; dash line = zirconium solution). 
tartaric acid was examined in greater detail. The thorium in the test solutions was varied from 0 to $150 \mathrm{y} \mathrm{MhO}_{2}$ and the zirconium from 100 to $1000 \gamma \mathrm{ZrO}_{2}$. The absorbance of each test solution was determined relative to a comparable reference solution containing the same amounts of all reagents but without zirconium, In figure 4 the data for solutions containing zero and $150 \gamma \mathrm{ThO}_{2}$ and $\mathrm{O}_{0.1}$ to $0.5 \mathrm{ml}$ of tartaric acid are shown. Higher concentrations of tartaric acid were eliminated because of the slightly greater zirconium interference at low concentrations of zirconium. Other. curves for intermediate amounts of $\mathrm{ThO}_{2}$ fall in proper sequence between the Iimits shown in figure 4. If an absorbance difference of 0.0.11 (whieh is equivalent to $1 \gamma \mathrm{ThO}_{2}$ ) is taken as the maximum allowable error, the zirconium. Interference would be least at a level of tartaric acid between $0.3 \mathrm{ml}$ and $0.5 \mathrm{ml}$. Differences here are small and the $0.3-\mathrm{ml}$ level of tartaric acid was selected for the operating system. The operating conditions adopted for system I follow: In a total volume of $25 \mathrm{ml}$ are contained $1 \mathrm{ml}$ of (1+1) hydrochloric acid, $1 \mathrm{ml}$ of 0.1 percent hydroxylamine hydrochloride, $0.3 \mathrm{ml}$ of 30 percent tartaric acid, and $2 \mathrm{ml}$ of 0.1 percent thoron. In the final procedure $1 \mathrm{ml}$ of 9 percent tartaric acid is substituted for ease in pipetting. Undex the operating conditions of system I, the effect of varicus elements usually found in thorium ores, calculated as oxides, are given in table 1. Absorbances were determined differentially in $5 \mathrm{-cm}$ cells. The amount of each element is equivalent to an error of 1 . ThO $\mathrm{O}_{2}$ at the various levels of thorium. The cations were introduced as chlorides and anions as the sodium. salts, Niobium and tantalum solutions were prepared by fusing each oxide (purity $>99.5$ percent) with $\mathrm{K}_{2} \mathrm{CO}_{3}$ and leaching the melts with water to give very dilute solutions. The titanium solution was prepared by fusing $\mathrm{IO}_{2}$ with $\mathrm{K}_{2} \mathrm{CO}_{3}$ and dissolving the melt in $(1+9)$ hydrochloric acid. The rare earths 


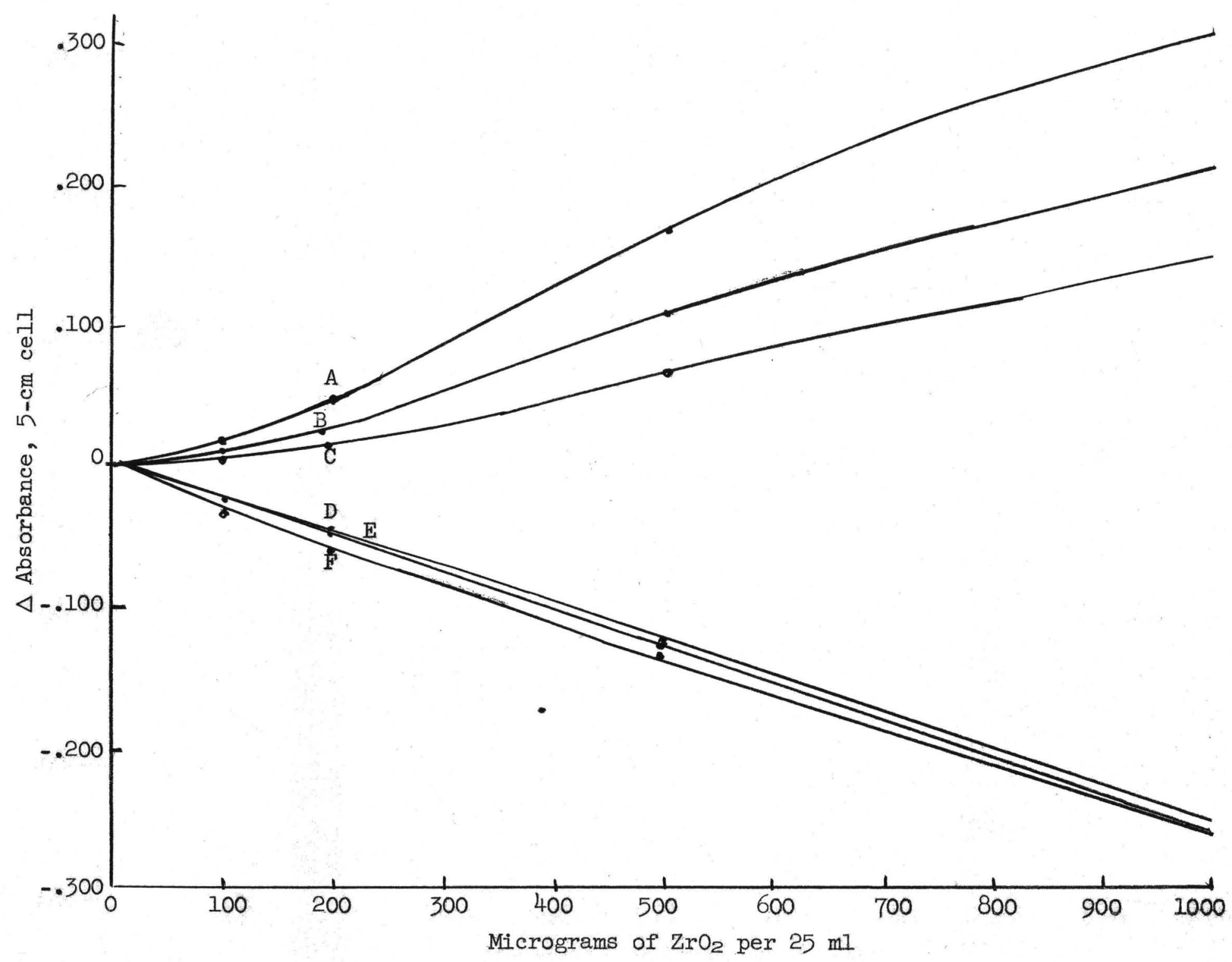

Figure 4.--Effect of zirconium at various concentrations of thorium and tartaric acid (zero ThO $0_{2-\infty}$ $A=0.1 \mathrm{ml} 30$ percent tartaric acid; $B=0.3 \mathrm{ml} 30$ percent tartaric acid; $C=0.5 \mathrm{ml}$. 30 percent tartaric acid; $150 \gamma \mathrm{Th} \mathrm{O}_{2}-\mathrm{D}=0.1 \mathrm{ml} 30$ percent tartaric acid; $\mathrm{E}=0.3 \mathrm{ml} 30$ percent tartaric acid; $F=0.5 \mathrm{ml} 30$ percent tartaric acid). 
Table 1.--Milligrams of various elements (as oxides) equivalent to 1 microgram of thorium dioxide.

\begin{tabular}{|c|c|c|c|c|c|c|c|}
\hline \multirow{2}{*}{$\begin{array}{l}\text { Elements } \\
\text { tested }\end{array}$} & \multicolumn{4}{|c|}{$(5 \mathrm{mI}$ of $0.04 \%$ thoron, $1 \mathrm{mI}$ of $9 \%$ tartaric acid $)$} & \multicolumn{3}{|c|}{$\begin{array}{l}\text { System II } \\
(5 \mathrm{ml} \text { of } 0.08 \% \text { thoron, I } \mathrm{ml} \\
\text { of } 30 \% \text { tartaric acid })\end{array}$} \\
\hline & at $\mathrm{O}-\mathrm{ThO}_{2}$ & at $10 \mathrm{Y} \mathrm{ThO} \mathrm{O}_{2}$ & at $100 \mathrm{\gamma} \mathrm{ThO}_{2}$ & at $150 \mathrm{\gamma} \mathrm{ThO}_{2}$ & at $\mathrm{O}-\mathrm{ThO}_{2}$ & at $50 \mathrm{\gamma} \mathrm{ThO}_{2}$ & at $150 \% \mathrm{ThO}_{2}$ \\
\hline $\mathrm{Sc}_{2} \mathrm{O}_{3}$ & 0.52 & 0.18 & 0.070 & 0.070 & 0.63 & 0.11 & 0.10 \\
\hline $\mathrm{Y}_{2} \mathrm{O}_{3}$ & 3.5 & 3.5 & 7.5 & $>7.5$ & 2.0 & 2.5 & 2.7 \\
\hline $\mathrm{La}_{2} \mathrm{O}_{3}$ & 0.72 & 0.72 & 1.0 & - & 0.35 & 0.77 & 2.5 \\
\hline $\mathrm{Ce}_{2} \mathrm{O}_{3}$ & 0.46 & 0.70 & 1.2 & 1.8 & 0.34 & 0.50 & 0.72 \\
\hline $\mathrm{Pr}_{2} \mathrm{O}_{3}$ & 0.74 & 0.76 & 0.96 & - & 0.49 & 0.50 & 0.85 \\
\hline $\mathrm{Nd}_{2} \mathrm{O}_{3}$ & 0.88 & 0.96 & 1.6 & 1.7 & 0.48 & 0.63 & 0.71 \\
\hline $\mathrm{Sm}_{2} \mathrm{O}_{3}$ & 0.68 & 0.72 & 0.95 & 0.95 & 0.58 & 0.58 & 0.82 \\
\hline $\mathrm{Eu}_{2} \mathrm{O}_{3}$ & 1.9 & 1.9 & 1.9 & $-\infty$ & 0.81 & 1.2 & 1.6 \\
\hline $\mathrm{Gd}_{2} \mathrm{O}_{3}$ & 2.8 & 2.8 & 2.8 & - & 1.2 & 1.7 & 1.7 \\
\hline $\mathrm{Tb}_{2} \mathrm{O}_{3}$ & - & - & $>5.0$ & - & 1.4 & - & $-\infty$ \\
\hline $\mathrm{Dy}_{2} \mathrm{O}_{3}$ & - & - & - & -- & - & -- & -- \\
\hline $\mathrm{HO}_{2} \mathrm{O}_{3}$ & - & $-\infty$ & $>5.0$ & - & - & -- & $-\infty$ \\
\hline $\operatorname{Er}_{2} \mathrm{O}_{3}$ & - & - & $>5.0$ & - & 3.6 & - & - \\
\hline $\operatorname{Tm}_{2} \mathrm{O}_{3}$ & - & - & $>6.0$ & - & - & - & $-\infty$ \\
\hline $\mathrm{Yb}_{2} \mathrm{O}_{3}$ & $>5.0$ & $>5.0$ & $>5.0$ & - & 3.1 & $-\infty$ & 4.8 \\
\hline
\end{tabular}


Table 1.m-Miligramis of various elements (as oxides) equivalent to I microgram of thorium dioxide-chontinued.

\begin{tabular}{|c|c|c|c|c|c|c|c|}
\hline \multirow{2}{*}{$\begin{array}{c}\text { Elements } \\
\text { tested }\end{array}$} & \multicolumn{4}{|c|}{$\begin{array}{c}\text { System } I \\
(5 \mathrm{ml} \text { of } 0.04 \% \text { thoron, I } \mathrm{ml} \text { of } 9 \% \text { tartaric acid) }\end{array}$} & \multicolumn{3}{|c|}{$\begin{array}{l}\text { (5ystem II } \\
\text { of of } 0.08 \% \text { thoron, I mI } \\
\text { of } 30 \% \text { tartaric acid })\end{array}$} \\
\hline & at $0-\mathrm{ThO}_{2}$ & at $10 \gamma \mathrm{ThO}_{2}$ & at $100 \gamma \mathrm{ThO}_{2}$ & at $150 \gamma \mathrm{ThO}_{2}$ & at $\mathrm{O}-\mathrm{ThO}_{2}$ & at $50 \gamma$ ThOz & at $150 \mathrm{\gamma} \mathrm{ThO}_{2}$ \\
\hline $\mathrm{Lu}_{2} \mathrm{O}_{3}$ & $-\infty$ & -- & $>5.0$ & $\ldots$ & 4.0 & $>5.0$ & $-\infty$ \\
\hline $\mathrm{TiO}_{2}$ & 1.0 & 0.040 & 0.016 & 0.013 & 0.50 & 0.021 & 0.014 \\
\hline $\mathrm{ZrO}_{2}$ & 0.13 & 0.13 & 0.18 & 0.045 & 0.34 & 0.36 & $>1.0$ \\
\hline $\mathrm{Nb}_{2} \mathrm{O}_{5}$ & 0.20 & $=0.40$ & 0.060 & 0.043 & 0.83 & 0.060 & 0.050 \\
\hline $\mathrm{Ta}_{2} \mathrm{O}_{5}$ & 0.10 & 0.25 & 0.13 & 0.04 & 0.59 & 0.090 & 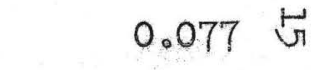 \\
\hline $\mathrm{WO}_{3}$ & $>5.0$ & 2.8 & 1.0 & 0.50 & $>5.0$ & 3.0 & 4.7 \\
\hline $\mathrm{UO}_{3}$ & 0.54 & 0.54 & 1.3 & 2.4 & 0.28 & 0.38 & 0.47 \\
\hline $\mathrm{Fe}_{2} \mathrm{O}_{3}$ & 0.35 & 0.18 & 0.15 & 0.14 & 0.13 & 0.045 & 0.028 \\
\hline $\mathrm{Au}_{2} \mathrm{O}_{3}$ & $>5.0$ & $>5.0$ & $>5.0$ & $>5.0$ & $>5.0$ & $>5.0$ & $>5.0$ \\
\hline $\mathrm{HgO}$ & $>20$ & $>20$ & $>20$ & $>20$ & $>20$ & $>20$ & $>20$ \\
\hline $\mathrm{Al}_{2} \mathrm{O}_{3}$ & 44 & 82 & 50 & 23 & 2.3 & 3.0 & 8.5 \\
\hline $\mathrm{SnO}_{2}$ & 0.060 & 0.060 & 0.079 & 0.098 & 0.056 & 0.094 & 0.078 \\
\hline $\mathrm{PbO}$ & $>10$ & $>10$ & $>10$ & $>10$ & 5.0 & 10 & 10 \\
\hline $\mathrm{Bi}_{2} \mathrm{O}_{3}$ & $-\infty$ & $-\infty$ & $-\infty$ & -- & $>5.0$ & $>5.0$ & $>5.0$ \\
\hline $\mathrm{P}_{2} \mathrm{O}_{5}$ & $>5.0$ & 2.0 & 0.16 & 0.065 & $>5.0$ & 0.70 & 0.60 \\
\hline $\mathrm{SO}_{3}$ & $>5.0$ & 4.3 & 0.60 & 0.32 & $>5.0$ & 2.2 & 2.2 \\
\hline$F$ & $>5.0$ & 0.0064 & 0.001 & 0.0006 & $>2.0$ & 0.005 & 0.0027 \\
\hline
\end{tabular}


were spectrographically pure and determined to be free from thorium and zirconium by chemical tests.

\section{System II}

In system II, the amount of thoron was increased to $4 \mathrm{mg}$. The effect of tartaric acid on solutions containing 200 to $1000 \gamma \mathrm{ZrO}$ alone and in the presence of $150 \gamma$. ThO $\mathrm{O}_{2}$ is shown in figure 5. The absorbance differences from solutions free from zirconium but containing the same amounts of other reagents are plotted. One milliliter of tartaric acid was chosen as optimum. The operating conditions for system II are thus the same as in system I except for the substitution of $1 \mathrm{ml}$ for $0.3 \mathrm{ml}$ of 30 percent tartaric acid and of $4 \mathrm{mg}$ of thoron for $2 \mathrm{mg}$ of thoron. The effect of various elements under these conditions are given in table 1 .

The effects of thoron concentration at the $0.3-\mathrm{ml}$ and $1.0 \mathrm{-ml}$ levels of tartaric acid, other conditions being the same, are illustrated in figure 6 . We have data showing that in the thorium complex the ratio of thoron to thorium is 2 to 1. A calculated absorbance-thorium concentration curve for $0.3 \mathrm{ml}$ of tartaric acid and $2 \mathrm{mg}$ of dye was found to be within 5 percent of the experimental curve. The 5 percent difference can be accounted for by the small amount of thorium complexed by tartaric acid. The effect of pH under the operating conditions of system II is illustrated in figure 7. One milliliter of $(1+I)$ HCI was used in the reference solution. Only slight changes in absorbancy with increasing acidity show that the pH dependency is not too important. Similar considerations hold for system I.

The effects of various elements, system II, are given in table l. Higher concentrations of rare earths, iron, aluminum, and uranium can be tolerated in system I than in system II. 


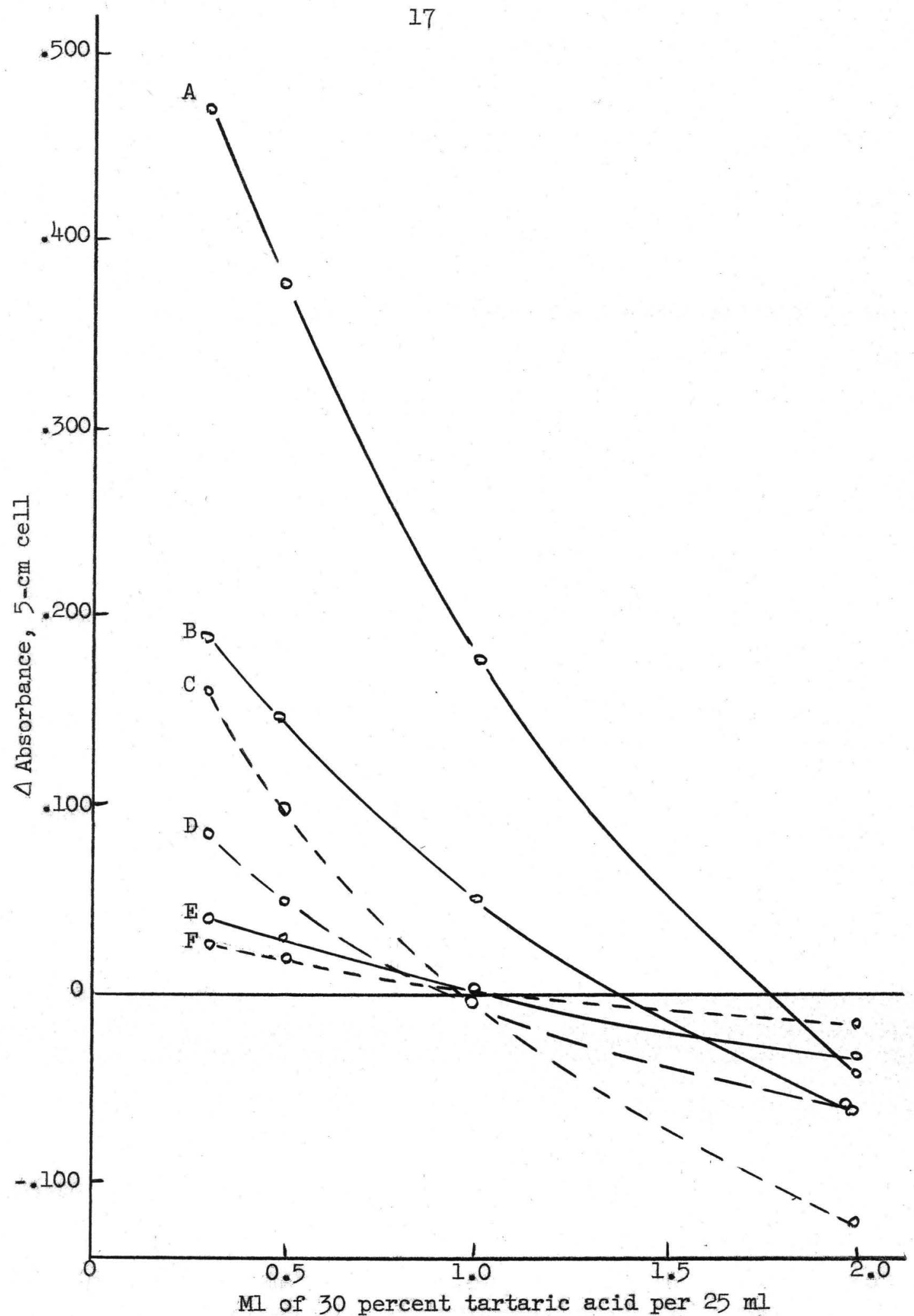

Figure 5.--Effect of tartaric acid, System II (A, I mg $\mathrm{ZrO}_{2} ; \mathrm{B}, 500 \gamma \cdot \mathrm{ZrO}_{2}$; $\mathrm{E}, 200 \gamma \mathrm{ZrO}_{2} ; \mathrm{C}, 150 \gamma \mathrm{ThO}_{2}+1 \mathrm{mg} \mathrm{ZrO}_{2} ; \mathrm{D}, 150 \gamma \mathrm{ThO}_{2}+500 \gamma \mathrm{ZrO}_{2}$; $\left.\mathrm{F}, 150 \gamma \mathrm{ThO}_{2}+200 \gamma \mathrm{ZrO}_{2}\right)$. 


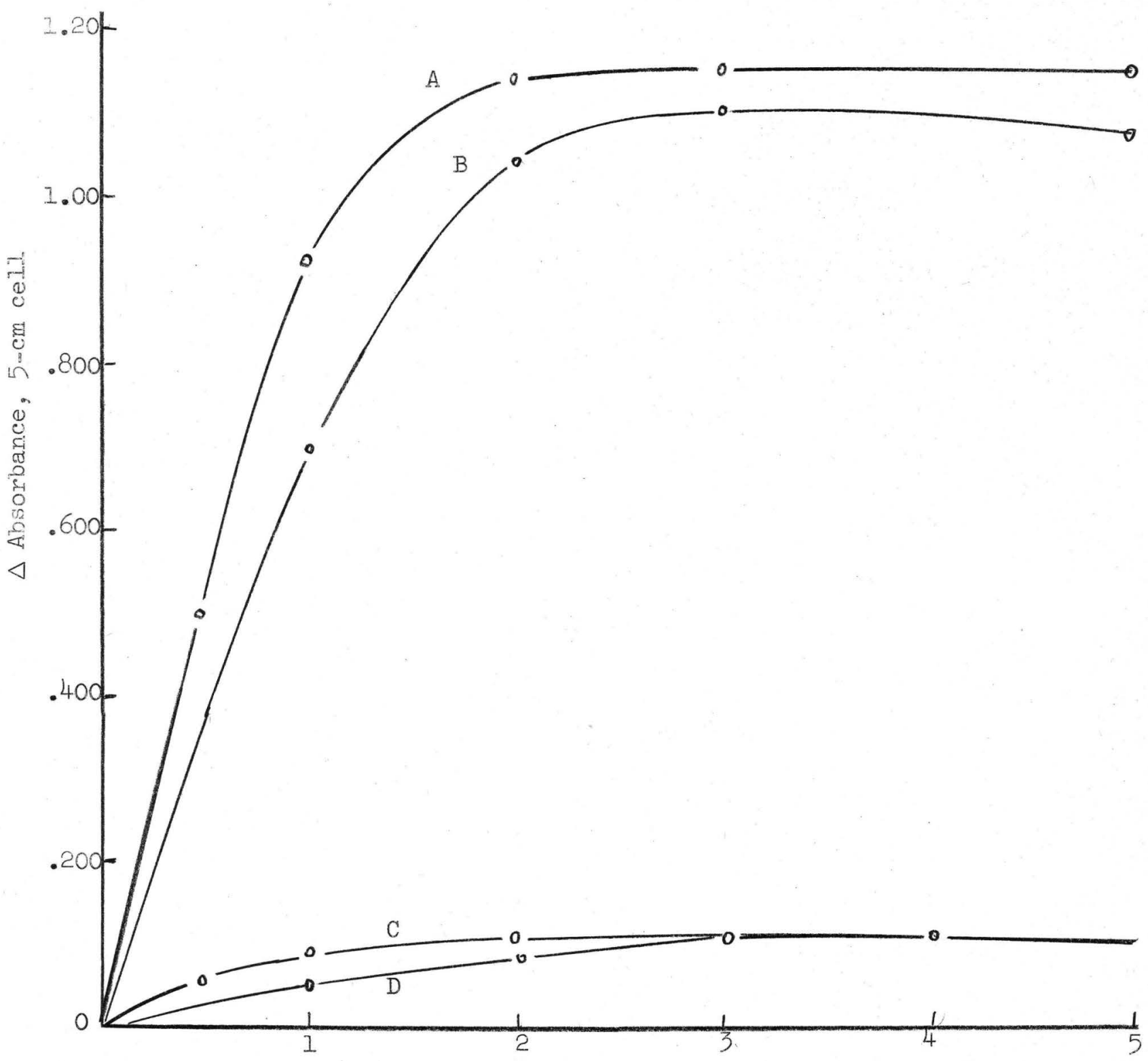

M] of 0.1 percent thoron per $25 \mathrm{~m} I$

Figure 6.--Effect of thoron concentration (A, C, System I; $\mathrm{B}, \mathrm{D}$, System II; A, B, $\left.100 \gamma \mathrm{ThO}_{2}: \mathrm{C}, \mathrm{D}, 10 \gamma \mathrm{ThO}_{2}\right)$. 


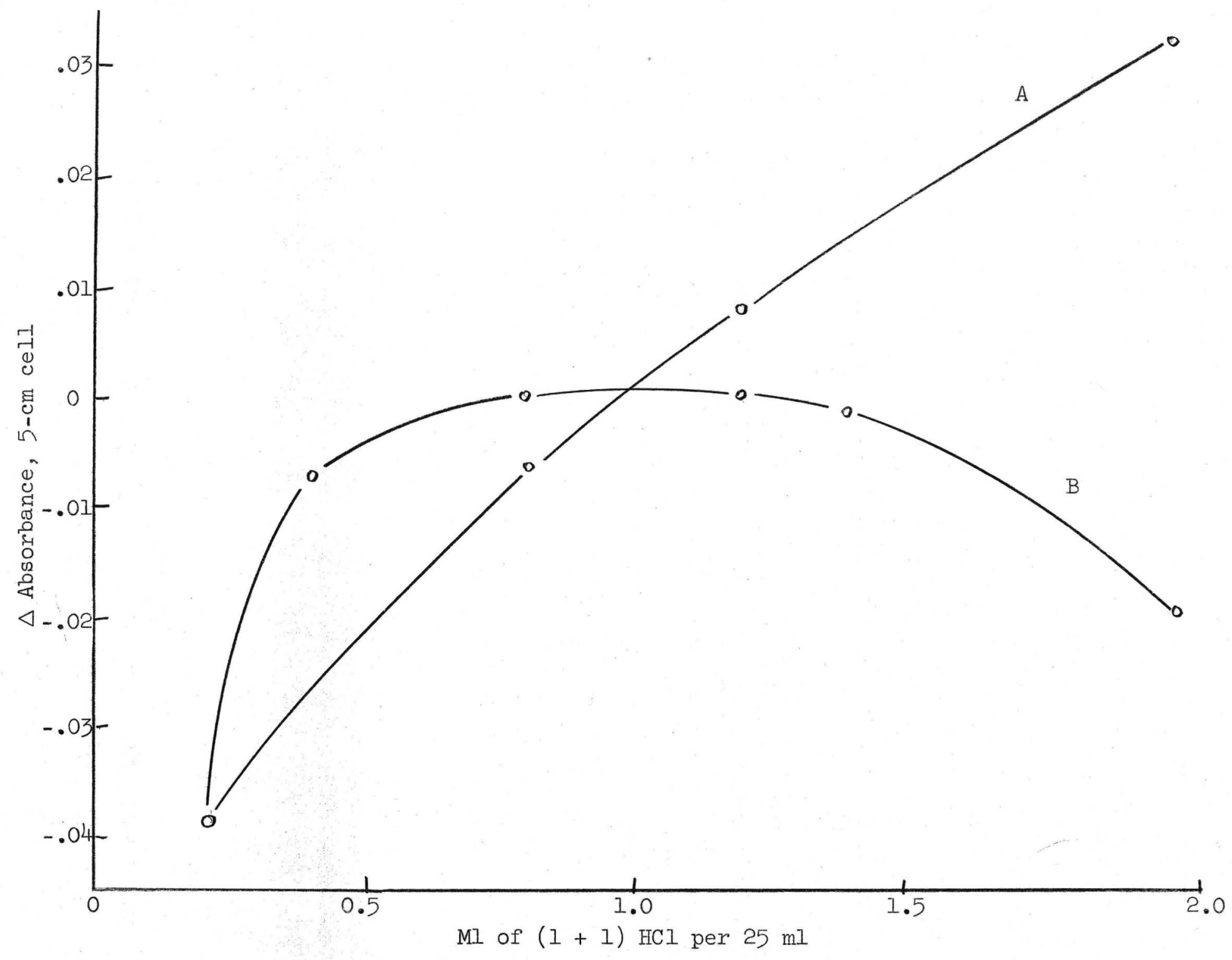

Figure 7.--Effect of acidity, system II (A. $15 \mathrm{\gamma} \mathrm{ThO_{2 }} ; \mathrm{B} .100 \mathrm{\gamma} \mathrm{ThO}_{2}$ ). 
System II can tolerate higher concentration of anions as well as zirconium and tungsten.

\section{System III}

Two milligrams of thoron was used in system III which is similar to system I except that meso-tartaric acid was substituted for the d-form used in systems I and II. The effect of meso-tartaric acid on the absorbances of thoron and various solutions containing thorium or zirconium or both are shown in figure 8. Absorbances were obtained differentially but are plotted with respect to water as reference. A simple system is indicated without the complications exhibited by d-tartaric acid systems. It seems that mesotartaric acid should be an ideal reagent to mask at least $1 \mathrm{mg}$ of $\mathrm{ZrO}_{2}$. The system appears promising and will be the subject of a separate study. Present work on the meso-tartaric acid system has had to be suspended pending the results of inquiries on the cost and availability of the reagent.

\section{SPECTROPHOTOMEIRIC DETERMINATION OF \\ THORIUM IN MONAZITE CONCENTRATEES}

By the use of a dilution technique and measuring absorbances with a 5-cm light path, it was found possible to determine thorium in monazite sands directly after the solution of the sample. An a.liquot representing $0.5 \mathrm{mg}$ of sample is used for the spectrophotometric determination.

\section{Reagents and apparatus}

Thoron solution, system $\mathrm{I}, 0.04 \mathrm{~g}$ per $100 \mathrm{ml}$ of aqueous solution. Thoron solution, system II, $0.08 \mathrm{~g}$ per $100 \mathrm{ml}$ of aqueous solution. d-Tartaric acid solution, system I, $9 \mathrm{~g}$ per $100 \mathrm{ml}$ of aqueous solution. 


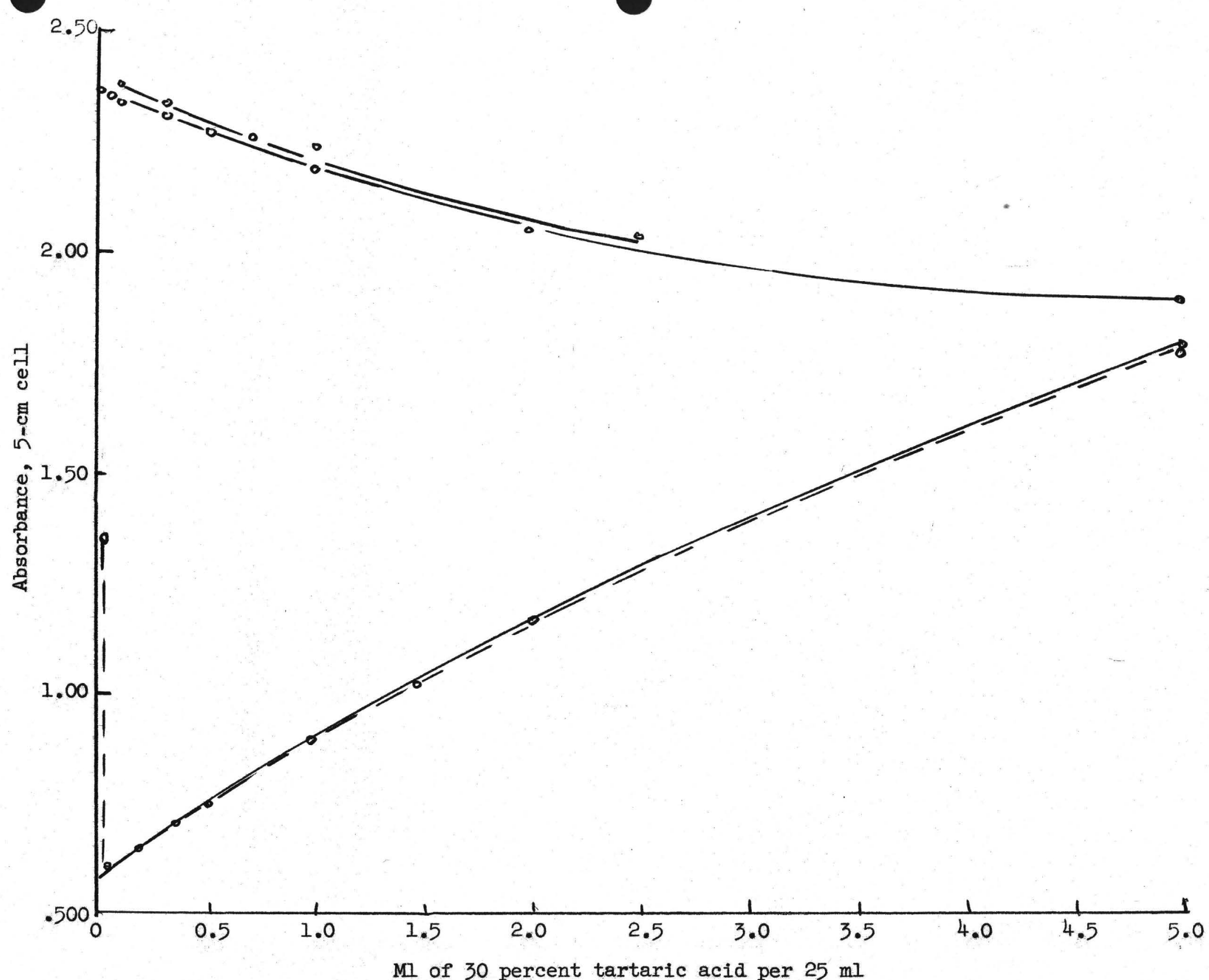

Figure 8.--Effect of meso-tartaric acid, system III (uppermost curve--150 $\gamma \mathrm{ThO}_{2}+1 \mathrm{mg} \mathrm{ZrO}_{2}$; next--150 $\gamma \mathrm{ThO}_{2}$; dashed--I mg $\mathrm{ZrO}_{2}$; lowest solid--reagent blank). 
d-Tartaric acid solution, system II, $30 \mathrm{~g}$ per $100 \mathrm{ml}$ of aqueous solution. Hydroxylamine hydrochloride solution, $10 \mathrm{~g}$ per $100 \mathrm{ml}$ of aqueous solution. Beckman Model DU spectrophotometer supplied with 5-cm cells.

\section{Procedure}

1. Mix $0.1000 \mathrm{~g}$ of a representative finely ground monazite sample with I $g$ of sodium peroxide in a platinum crucible.

2. Sinter the mixture (covered) in a small furnace at $440 \pm 20^{\circ} \mathrm{C}$ for about 30 minutes. At higher temperatures $\mathrm{Na}_{2} \mathrm{O}_{2}$ would seriously attack the platinum vessel. In the range $440 \pm 20^{\circ} \mathrm{C}$ the platinum crucible is hardly attacked.

3. Leach with 25 to $50 \mathrm{ml}$ water. Digest the solution on the steam bath until the precipitate is filterable.

4. Filter the solution through a medium speed filter paper and wash with 1 percent potassium hydroxide solution. A clear filtrate should be obtained. If not, the filtrate is digested and refiltered.

5. Dissolve the residue off the paper with $20 \mathrm{ml}$ of hot (I+I) HCI (use pipet) adding a drop or two of hydrogen peroxide (30 percent) to reduce cerium to the trivalent state. Wash thoroughly with water. The filtrate should be about $40 \mathrm{ml}$.

6. Remove hydrogen peroxide by heating the solution on the steam bath in a covered beaker for about 30 minutes. Cool.

7. Transfer the solution to a 100-ml volumetric flask and adjust to mark with water. Mix.

8. Transfer a $10-\mathrm{ml}$ aliquot to a dry 100-ml volumetric flask. Add (I+9) HCl to the mark. Mix. 
9. Transfer a 5-ml aliquot to a 25-ml volumetric flask. Add I ml of hydroxylamine hydrochloride. Add $5 \mathrm{ml}$ of water. If system $I$ is used, add $1 \mathrm{ml}$ of 9 percent tartaric acid solution and $5 \mathrm{ml}$ of 0.04 percent thoron solution. Adjust to mark with water and $\mathrm{mix}$. If system II is used, add I $\mathrm{ml}$ of 30 percent tartaric acid solution and $5 \mathrm{ml}$ of 0.08 percent thoron solution. Adjust to the mark with water and mix. Volumetric pipets are used throughout.

10. Measure the absorbance of the solution in 5-cm cells against a reagent blank. The reagent blank is prepared by adding $1 \mathrm{ml}$ each of $(1+1)$ $\mathrm{HCl}$, hydroxylamine hydrochloride, the proper tartaric acid, and $5 \mathrm{ml}$ of the proper thoron solution. Absorbances are measured with the Beckman DU spectrophotometer at $545 \mathrm{m \mu}$ using a slit width of 0.05 for system I and 0.15 for system II.

11. Determine the amount of thorium by reference to a standard curve. The relationship between absorbance and thorium concentration is linear up to $100 \gamma \mathrm{ThO}_{2}$ for system I and up to $60 \gamma \mathrm{ThO}_{2}$ for system II. For amounts of ThO $\mathrm{O}_{2}$ greater than these limits, the curvature is very gentle and all points are reproducible. The systems are stable enough so that absorbance measurements can be made at any time within 1 hour.

Note: The suggested dilution procedure is peculiarily suited for the determination of thorium in monazite concentrates because the ratios of titanium and other interfering ions to thorium are usually sufficiently low in these ores. The dilution technique should find use on other samples provided that the final aliquot contains smaller amounts of interfering elements than given in table 1. Ordinarily titanium and iron determine the limits of applicability. For an aliquot containing $0.5 \mathrm{mg}$ of sample, no more than 4 percent $\mathrm{TiO}_{2}$ and at least 1 percent $\mathrm{ThO}_{2}$ should be present. Iron 
need not be a serious interference if it is reduced to the bivalent state in which form at least $10 \mathrm{mg}$ can be tolerated. For the reduction of iron the final aliquot (which is acid) is evaporated to dryness, $1 \mathrm{ml}$ of hydroxylamine hydrochloride solution is added, and the mixture warmed briefly. At the low acidity of such solutions the reduction of iron is instantaneous. After the reduction, water, hydrochloric acid, tartaric acid, and thoron are added for the color development.

\section{Test of procedure}

A standard monazite sand, no, 2601, obtained from the New Brunswick Iaboratory of the U. S. Atomic Energy Commission, was analyzed according to the proposed procedure. Three aliquots of the solution were analyzed by the method of system I and three aliquots of the same solution were analyzed by the method of system. II. The results are given in table 2.

Table 2.--Test of procedure on monazite sand.

$\left.\begin{array}{lll}\text { Sample no. } & \text { System I } & \begin{array}{c}\text { Pereent ThO } \\ \text { System II }\end{array} \\ \text { NBS 2601 } & 9.88 & 9.80 \\ \text { Do. } & 9.88 & 9.78 \\ \text { Do. } & 9.88 & 9.82\end{array}\right\}$

\section{ACKNOWLEDCMENIS}

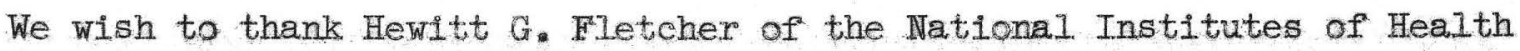
for his generosity in supplying the meso-tartaric acid. This work is part of a program being conducted by the U. S. Geological Survey on behalf of the Division of Raw Materials of the U. S. Atomic Energy Commission. 
1. Banks, C. V., and. Byrd, C. H., 1953, Spectrophotometric determination of thorium in monazite sands: Anal. Chemistry 25, 416.

2. Banks, C. V., Klingman, D. W., and Byrd, C. H., 1953, Spectrophotometric determination of thorium in black sands: Anal. Chemistry 25, 992.

3. Byrd, C. H., and Banks, C. V., 1953, Spectrophotometric determination of thorium with the trisodium salt of 2-(2-hydroxy-3,6-disulfo-l-naphthylazo)benzenearsonic acid and some properties of complexes involved: ISC-456, Iowa State College.

4. Ingles, J. C., 1951, The chemical determination of thorium in its ores: NP-3069, Canada Dept. Mines Tech. Surveys, Mines Branch.

5. Kuznetsov, V. I., 1944, Color reaction of thorium, I: Jour. Gen. Chem. (U.S.S.R.) 14, 914 .

6. Taylor, A. E., and Dillon, R. T., 1952, Determination of microgram amounts of thorium in water: Anal. Chemistry 24, 1624.

7. Thomason, F. F., Perry, M. A., and Byerly, W. M*, 1949, Determination of microgram amounts of thorium: Anal. Chemistry $21,1239$. 